Corrigendum

\title{
Corrigendum to "HDAC and HMT Inhibitors in Combination with Conventional Therapy: A Novel Treatment Option for Acute Promyelocytic Leukemia"
}

\author{
Aida Vitkevičienė $\mathbb{D}^{1},{ }^{1}$ Giedrè Skiauterytė, ${ }^{1}$ Andrius Žučenka, ${ }^{2,3}$ Mindaugas Stoškus $\mathbb{D}^{2}{ }^{2}$ \\ Eglè Gineikienè, ${ }^{2}$ Veronika Borutinskaitè ${ }^{(D)}{ }^{1}$ Laimonas Griškevičius, ${ }^{2,3}$ \\ and Rüta Navakauskiené $\left.{ }^{1}\right)^{1}$ \\ ${ }^{1}$ Department of Molecular Cell Biology, Institute of Biochemistry, Life Sciences Center, Vilnius University, Sauletekio Av. 7, \\ LT-01257 Vilnius, Lithuania \\ ${ }^{2}$ Hematology, Oncology, and Transfusion Medicine Centre, Vilnius University Hospital Santaros Klinikos, Santariskiu Str. 2, \\ LT-08661 Vilnius, Lithuania \\ ${ }^{3}$ Institute of Clinical Medicine, Vilnius University, M. K. Ciurlionio Str. 21, LT-03101 Vilnius, Lithuania \\ Correspondence should be addressed to Aida Vitkevičiené; aida.vitkeviciene@gmc.vu.lt
}

Received 7 August 2020; Accepted 7 August 2020; Published 4 September 2020

Copyright (c) 2020 Aida Vitkevičienè et al. This is an open access article distributed under the Creative Commons Attribution License, which permits unrestricted use, distribution, and reproduction in any medium, provided the original work is properly cited.

In the article titled "HDAC and HMT Inhibitors in Combination with Conventional Therapy: A Novel Treatment Option for Acute Promyelocytic Leukemia" [1], the last author was mistakenly linked to the second affiliation instead of the first. The corrected author list and affiliations are shown above.

\section{References}

[1] A. Vitkevičienè, G. Skiauteryte, A. Žučenka et al., "HDAC and HMT inhibitors in combination with conventional therapy: a Novel treatment option for acute promyelocytic leukemia," Journal of Oncology, vol. 2019, Article ID 6179573, 11 pages, 2019. 